\title{
Preparing for Poison Warfare: The Ethics and Politics of Britain's Chemical Weapons Program, 1915-1945
}

\author{
Ulf Schmidt
}

\begin{abstract}
Allied political and military leaders have frequently been credited both with considerable foresight and with strategic and moral leadership for avoiding chemical warfare during the Second World War. Scholars have not, however, fully acknowledged how close Allied forces came to launching a full-scale chemical onslaught in various theatres of war. The paper offers a thorough reconstruction of Allied chemical warfare planning which takes a close look at the development of Britain's chemical weapons program since the First World War. The findings suggest that no "lack of preparedness," as it existed in the initial stages of the conflict in 1939/1940, would have deterred the Allies from launching chemical warfare if the military situation had required it. Allied forces were planning to launch retaliatory chemical warfare ever since they had been attacked with chlorine gas in 1915. Just War theorists at first opposed the use of this new weapon and campaigned for an internationally enforced legal ban. The paper argues, however, that post-war military and political exigencies forced the advocates of the Just War tradition to construct new arguments and principles which would make this type of war morally and militarily acceptable. The paper explores the ways in which military strategists, scientists, and government officials attempted to justify the development, possession, and use of chemical weapons, and contextualizes Britain's delicate balancing act between deterrence and disarmament in the interwar period.
\end{abstract}

\section{Introduction}

Allied political and military leaders have frequently been credited both with considerable foresight and with strategic and moral leadership for avoiding chemical warfare during the Second World War. Scholars have not, however, fully acknowledged how very close Allied forces came to launching a full-scale chemical

\footnotetext{
U. Schmidt $(\bowtie)$

University of Kent, Canterbury, UK

e-mail: U.I.Schmidt@kent.ac.uk

(C) The Author(s) 2017

B. Friedrich et al. (eds.), One Hundred Years of Chemical Warfare: Research,

Deployment, Consequences, DOI 10.1007/978-3-319-51664-6_6
} 
onslaught in the European and far eastern theaters of war. ${ }^{1}$ Although Allied intelligence was aware of Japan's chemical warfare operations against China, which had commenced in 1937, the Allied military decided against retaliatory measures. ${ }^{2}$ Chemical warfare would not only have violated international law and morality as it was known and understood at the time, but would have changed beyond recognition the image and conduct of modern warfare for generations to come. The fact that a potentially devastating event did not happen is seen as tangible evidence of the underlying morality and humanity of Western governments in defending modern civilization. A more thorough reconstruction of Allied chemical warfare planning, as is proposed here, one which incorporate and takes a close look at the development of Britain's chemical weapons program since the First World War, allows us to recognize that no "lack of preparedness," however serious it may have been in the initial stages of the conflict, would have deterred the Allies from launching chemical warfare if the military situation had required it. Allied forces were indeed planning for chemical warfare ever since they had been attacked with chlorine gas in $1915 .^{3}$

From the moment chemical weapons appeared on the stage of armed conflict, Just War theorists opposed the use of this new weapon and campaigned for an internationally enforced legal ban. Chemical weapons, they argued, violated the requirement for non-combatant immunity because they indiscriminately killed and injured children, women, and the elderly. In the 1920s, however, military and political exigencies forced the advocates of the Just War tradition to construct new arguments and principles that would make this type of war morally and militarily acceptable. Responding to an international legal ban on poison gas, government experts began to condemn the inhumanity of armed conflict, while simultaneously accepting the need for this type of warfare in certain circumstances. There is therefore a need to examine the ways in which military strategists, scientists, diplomats, and government officials attempted to justify the development, possession, and use of chemical weapons through different means and methods of propaganda, and to contextualize Britain's delicate balancing act between deterrence and disarmament in the postwar period.

\footnotetext{
${ }^{1}$ For some of the scholarship on the history of biological and chemical warfare since the First World War see SIPRI (1971); Harris and Paxman (1982); Haber (1986); Richter (1994); Evans (2000); Balmer (2001); Hammond and Carter (2002); Schmaltz (2005, 2006a, b, c); Wheelis et al. (2006); Tucker (2006); Schmidt (2006, 2007a, b, 2013); Schmidt and Frewer (2007); Spiers (2010); Avery (2013). For a comprehensive analysis of chemical warfare research and human experiments during the twentieth and twenty-first centuries, see also Schmidt (2015). Sections of this chapter have been reproduced with permission by Palgrave published in Schmidt (2012).

${ }^{2}$ See Van Moon and Ellis $(1989,1996)$.

${ }^{3}$ Spiers, for instance, suggests that "lack of preparedness was a principal reason for non-use of chemical or biological weapons between the major belligerents in the Second World War" (Spiers 2010, 57). For the use of chlorine in 1915 see Cowell et al. (2007).
} 


\section{Ypres 1915}

By the time the first major chemical warfare attack in modern history came to an end, the Allies had lost hundreds, if not thousands, of soldiers. Allied propaganda estimated that 5000 soldiers had been killed and 10,000 had been wounded, though these numbers are generally accepted to have been exaggerated (Szöllösi-Janze 1998, 318). ${ }^{4}$ Whatever the exact casualty figures, witness accounts confirmed that Allied troops had been exposed to one of the first weapons of mass destruction, which killed men slowly and painfully from within rather than wounding them on the outside. Total panic had gripped thousands of seasoned soldiers and civilians who fled from the toxic fumes; the modern battlefield had become a site of unimaginable horror and untold human suffering.

Despite a four-mile hole in the Western Front, and an enemy army in disarray, the German military, having failed to anticipate the effects of the "new infernal invention," as some called it, and lacking the necessary reserves to break through Allied defenses, was unable to exploit their sudden strategic advantage (Buffetaut 2008). Among those disappointed by the German lack of planning was the head of the Kaiser Wilhelm Institute in Berlin, Fritz Haber, who was instrumental in developing German chemical warfare agents. If only the military authorities had launched a full-scale offensive, he complained, "instead of the experiment at Ypres, the Germans would have won" (Harris and Paxman 1982, 10). Haber saw gas warfare as a more "humane" weapon of war:

The gas weapons are surely not more horrible than flying metal fragments, on the contrary, the percentage of deadly gas injuries is comparably smaller, there are no mutilations and nothing is known [...] in terms of follow-up injuries (Haber 1924, 35; see 25-41).

In 1919, much to the shock of the civilized world, Haber was awarded the Nobel Prize for Chemistry. ${ }^{5}$

Rejected as immoral and illegal by many, the new weaponry was greatly feared by the soldiers on the battlefield. Gas warfare became as much a psychological as a physical weapon. Often the experience of being gassed led to real and imagined clinical symptoms for years to come. The possibility of being killed by asphyxiating gases triggered deep-seated emotional responses and occasional nervous breakdowns which psychiatrists classified as "gas neurosis"; in other cases, soldiers exposed to blistering agents were classed as suffering from "gas hysteria," since the substances could cause conjunctivitis and temporary blindness (Harrison 2010, 106-109). Eyewitnesses recalled that "gas shock was as frequent as shellshock" (Shephard 2000, 64).

\footnotetext{
${ }^{4}$ Piet Chielens from the Flanders Fields Museum, Ypres, Belgium, has recently suggested that the number of "casualties" of the German gas attack near the Belgian town of Ypres in April 1915 was significantly lower than previously assumed (Chielens 2014; also Corrigan 2003, 164-165).

${ }^{5}$ For Haber's biography see Szöllösi-Janze (1998); Stolzenberg (2004); Charles (2005); see also the account by his son Lutz F. Haber in Haber (1986).
} 
No one had been prepared for this kind and scale of warfare; few had ever imagined that poison gas would be used; almost all were shocked that the world would never be the same, that armed conflict would forever be tainted by what many perceived to be an unmanly, dirty form of warfare. As early as 22 April 1915, Michel Toudy, a soldier of the Belgian Grenadiers tasked with strengthening front-line defenses in the immediate aftermath of the first gas attack, noted in his war diary: "Throughout the entire night French territorials arrive in our trenches coughing and saying that it is not permitted to attack aged family fathers with asphyxiating gas." $" 6$ Many Allied servicemen believed at this point that Germany had violated international conventions governing the conduct of war, which in many ways it had-if not the letter of the law, then certainly its spirit.

The German use of steel cylinders for the delivery of poison gas was meant to ensure that a large area would be cleared for a ground offensive once the gas had dissipated but it also had another, more profound rationale. Since the end of the nineteenth century, international law had prohibited the use of poison gas. Fearing that the ongoing arms race with Germany could weaken the fledgling Russian economy, and further destabilize the regime through strikes and revolutionary activities, Tsar Nicholas II had initiated the First Peace Conference in The Hague to revise and ratify the declarations about the laws and customs of war that had been negotiated in 1874 in Brussels. In 1899, representatives of twenty-six countries, including Britain, France, Russia, and Germany, had signed The Hague Convention Respecting the Laws and Customs of War, which not only regulated the treatment of prisoners of war and the care of sick and wounded, but also banned certain types of warfare and the use of modern technology, including aerial bombardment, chemical warfare, and hollow point bullets. Article 23(a) specifically prohibited the employment of "poison or poisoned arms."7 In a separately signed document, The Hague Declaration Concerning Asphyxiating Gases, the contracting states also pledged to outlaw the use of poison gas as a means of future warfare by "abstaining from the use of projectiles, the sole object of which is the diffusion of asphyxiating or deleterious gases" (Tucker 2006, 10f.). Attempting to ban weapons which did not yet exist, The Hague Declaration contained three major loopholes which the belligerents exploited during the First World War: the use of irritants, the employment of gas through means other than by using projectiles, and the use of gas-filled, yet shrapnel-causing bombs, were not covered by The Hague Declaration. Faced with a war of attrition, the German army was less concerned about the inherent legality or morality of gas warfare but more about semantics. Whereas the use of gas-filled projectiles was against international law, the German military considered the use of poison gas released from cylinders to be lawful. Days after Germany's first gas attack, the Kölnische Zeitung claimed that "the letting loose of smoke clouds,

\footnotetext{
${ }^{6}$ In Flanders Fields Museum, Documentation Centre, Toudy papers. I am grateful to Dominiek Dendooven for sharing this source with me. See also Dendooven (2005).

${ }^{7}$ Convention (II) with Respect to the Laws and Custom of War on Land and its Annex: Regulations Concerning the Laws and Customs of War on Land. The Hague, 29 July 1899.
} 
which, in a gentle wind, move quite slowly towards the enemy, is not only permissible by international law, but is an extraordinarily mild method of war" (Harris and Paxman 1982, 5). The Allied powers, however, described it as an act of inhumanity that violated "all codes of civilized behaviour" (SIPRI 1971, 231). It certainly did not bode well that the German military had given the poisonous cloud the code-name "Disinfection," a cover to confuse Allied intelligence, surely, but also one which portrayed enemy soldiers and civilians as vermin to be exterminated (Buffetaut 2008, 20).

Twenty-four hours after Germany's first gas attack, Sir John French, the Commander of the British Expeditionary Force, inquired about the existing supply of respirators and requested from London that "immediate steps be taken in retaliation to supply similar means of the most effective kind for the use of our own troops." In his reply, Lord Kitchener, the War Minister, called for caution: "The use of asphyxiating gases is, as you are aware, contrary to the rules and usages of war. Before we fall to the level of the degraded Germans I must submit the matter to the government." To investigate the matter, Kitchener called upon two civilian scientists: John S. Haldane (1860-1936), a former reader in physiology at Oxford University who, as director of a research laboratory in Doncaster, had worked with the mining industry in developing respirators against the toxic effects of mine gases; ${ }^{10}$ and Herbert B. Baker (1862-1935), a professor of chemistry at Imperial College. Both were dispatched to France to find out what kind of gas had been used and inspect the site of the first gas attack. At St Omer, close to the general headquarters in France, they managed to identify the gas that had been used as chlorine through the use of a school laboratory (Thorpe 1936, 525; also Foulkes 1934, 37). For all concerned, it was clear that "immediate defensive measures were required." 11 On their return to Britain, Haldane submitted a full report to Prime Minister Herbert Asquith, while Baker briefed Lord Kitchener about the situation; the latter told him to "do his damnedest" to ensure that Britain could soon retaliate (ibid.).

Despite these bold declarations of intent there was considerable uncertainty among members of the British government as to whether Germany had actually contravened the terms of The Hague Declaration. On 26 April, Asquith told King George V: "As the gases are apparently stored in and drawn from cylinders, and not "projectiles," the employment of them is not perhaps an infraction of the literal terms of The Hague Convention."12 Given that Germany was widely perceived as having violated the spirit of the Declaration, however, and with pressure mounting

\footnotetext{
${ }^{8}$ Foulkes 1934 (19); also Carter (2000, 2), who misquotes French in this instance.

${ }^{9}$ Foulkes (1934, 19f); Harris and Paxman (1982, 5); Hobbs et al. (2007, 260). See also TNA, WO142/241, correspondence between Sir John French and Lord Kitchener, 23-24 April 1915.

${ }^{10}$ For John S. Haldane see Douglas (1936); Sturdy (1987); Goodman (2008); Sturdy (2011); see also Haldane $(1925,63)$ who recounts how his father was sent to France to identify the gas which the Germans had used.

${ }^{11}$ TNA, WO188/802, p. 1.

${ }^{12}$ Hobbs et al. (2007, 260); TNA, CAB 37/127/40, Asquith to George V, 26 April 1915.
} 
on the War Office to retaliate, the government knew that such legal sophistry would have little truck with the British public.

Within days, after graphic accounts of gas casualties had been published by The Times and other newspapers, anti-German sentiment reached fever pitch (SIPRI 1971, 231ff.). On 29 April, The Times commented:

The willful and systematic attempt to choke and poison our soldiers can have but one effect upon the British people and upon all the non-German people of the earth. It will deepen our indignation and our resolution, and it will fill all races with a new horror of the German name. $^{13}$

On the same day, the Daily Mirror reported that the German military had again used "asphyxiating gases" contrary to The Hague Declaration. ${ }^{14}$ In Germany, meanwhile, gas warfare was portrayed as a modern weapon that was not only lawful but humane, one that produced a "rapid end" rather than the misery resulting from turning the German trenches "into a terrible hell."15 A week later, on 7 May, the sinking of the Lusitania off the coast of Ireland by a German U-boat, killing 1198 civilians on board, including American citizens, caused further international outrage and turned public opinion firmly against Germany (see also Spiers 2010, 40). By portraying Germany as an "inhuman enemy," and German soldiers as barbaric criminals, hell-bent on committing atrocities against civilians by means of poison gas and submarine warfare, and in flagrant violation of the rules of war, Allied officials managed to bring the United States into the conflict and justify, in the eyes of the public, Britain's retaliatory measures.

Germany's premeditated gas attack initiated a Europe-wide chemical arms race on an unprecedented scale, one in which there was "no time to worry about ethics" (Harris and Paxman 1982, 21). Even neutral Netherlands got involved in the production of hundreds of tons of poison gas (Van Bergen 2012). The German gas attack "both inspired and provoked the British into retaliating with illegal weaponry, thereby opening the door to a virtually unlimited chemical warfare" (in Hobbs et al. 2007, 261). After recovering from the initial shock, Britain and France wasted little time in establishing large-scale programs for the testing of toxic substances, and in preparing their armies for all-out technological warfare to be fought irrespective of any moral or legal boundaries. At the end of September 1915, British forces attempted, but largely failed, to use poison gas in a major offensive at Loos in Belgium (see Lloyd 2006). Despite months of preparation, the training of special gas brigades, the employment of chemical experts, and the shipment and positioning of thousands of gas-filled cylinders along the front line, military planners began to appreciate the enormous problems associated with chemical warfare. Gas warfare was highly unpredictable, scientifically complex, and dependent on prevalent weather and environmental conditions, and it quickly turned into a nightmare for military strategists. Whereas the human cost of the Battle of Loos was

\footnotetext{
${ }^{13}$ The Times, 29 April 1915, p. 9; also UoK, Porton Archive, A201, WWI CW Media Articles.

${ }^{14}$ Daily Mirror, 29 April 1915.

${ }^{15}$ Frankfurter Zeitung, 26 April 1915; quoted from SIPRI (1971, 232).
} 
substantial, strategic gains were almost negligible. The British had captured some 3000 German prisoners of war. Yet with over 50,000 British casualties, and hundreds of troops gassed by their own side-after the toxic cloud had changed direction - together with 3 miles of ground taken and then lost again, the military agreed that the machinery of war needed to be modernized if Britain and her Empire were to sustain a prolonged military campaign. Moreover, by using the newly developed Stokes mortar, the sole purpose of which was the delivery of chemical projectiles into and behind enemy lines, Britain had become the first nation to contravene the literal terms of The Hague Convention, and thus international law (Hobbs et al. 2007, 260f; also Spiers 1986, 24).

\section{Porton Down}

At the end of 1915, officials in the Ministry of Munitions concluded that the modern war machine needed nothing less than a fully equipped, large-scale testing ground to keep abreast of rapid developments in science, technology, and medicine. ${ }^{16}$ In September, the Trench Warfare Department duly instructed the Scientific Advisory Committee to find and requisition a suitable "ground for experimental purposes."17 A few months later, in early 1916, some 2886 acres of land near the villages of Idmiston, Idmiston Down, and Porton, on the southern edge of Salisbury Plain in Wiltshire, formed the basis of what came to be known as Porton Down. ${ }^{18}$

Porton rapidly expanded to take over 6200 acres of largely woodland and farmland, accessible through a complex network of roads and a light railway that interlinked the administrative headquarters, army huts, workshops, laboratories, munitions depot, open-air testing station, and animal farm, a place teeming with service personnel and civilian scientists working under the leadership of Porton's commandant, Lieutenant Colonel Arthur W. Crossley, a Mancunian, who had made his career as a chemist at King's College London. During the war, Porton was divided into four departments: the Commandant, the Division Officer Royal Engineers, the Works Department, and the Experimental Department. While the Division Officer Royal Engineers was responsible for the general upkeep of the facility, the Works Department, line-managed by the Superintendent of Experimental Grounds, carried out the construction work through civilian laborers. By 1918, the Experimental Department was divided into six sections: the Chemical Laboratory, the Anti-Gas Department, the Physiology Laboratory, the Meteorological Station, the Experimental Battery RA, and the Experimental

\footnotetext{
${ }^{16}$ TNA, WO188/802, p. 1.

${ }^{17}$ TNA, WO142/264, Lt Col A.W. Crossley RE, 'The Royal Engineers Experimental Station, Porton' (1919); also TNA, WO188/802, p. 1; Carter $(2000,3)$.

${ }^{18}$ TNA, WO142/264, Lt Col A.W. Crossley RE, "The Royal Engineers Experimental Station, Porton" (1919), pp. 3f. Work at the Station is believed to have commenced on 7 March 1916 when the first officer from the Royal Engineers reported for permanent duty.
} 
Company RE. ${ }^{19}$ As sign that Porton was there to stay, certainly for the duration of the war, the organization soon saw the creation of more permanent laboratories, photographic and meteorological units, barracks, and welfare facilities. By 1918, Porton had become a large-scale research facility with over 900 members of staff, many of them officers, thirty-three women from the Queen Mary Army Auxiliary Corps, who were employed as typists, and some 500 civilian workmen who maintained the workshops and laboratories. ${ }^{20}$ At first, much of the work was directed towards developing new weapons of mass destruction.

In September 1916, the first use of the Livens Projector, an ad hoc device consisting of a steel tube, about 3 feet in length and 8 inches wide, dug into the ground at an angle of $45^{\circ}$ in batteries of twenty, and detonated remotely through an electrical charge, opened a new chapter in gas warfare. It was no longer necessary to rely on the right meteorological conditions: bombs containing $30 \mathrm{lb}(15 \mathrm{~kg})$ of chemical agents, generally phosgene (CG), could be fired directly into enemy lines, resulting in high numbers of casualties and deaths. The power of the new weapon lay in the number of projectiles that could be fired simultaneously, sometimes more than 1000 at a time. ${ }^{21}$ In April 1917, at the Battle of Arras, the British used the Livens Projector for a full-scale, deadly attack. Although inexpensive and inaccurate, with a range limited to one mile, it was an effective but also terrifying weapon that served as a technological precursor to "multiple rocket launchers and... aircraft cluster bombs" (Harris and Paxman 1982, 22). Gas shells, on the other hand, used by Germany and France from 1916, required less preparation, offered greater targeting precision, and were able to be fired over longer distances. In Germany, the symbols on the shell cases represented the different chemical agents: a white cross stood for tear gas, a green cross for phosgene, and a yellow cross for mustard gas (HS). ${ }^{22}$ With an estimated total of 66 million gas shells fired during the war, chemical warfare had turned into an ever-present threat for Allied and German forces.

In December 1915, the German military used phosgene for the first time, an almost colorless and odorless gas, eighteen times more toxic than chlorine, which, when inhaled, caused serious lung damage from excessive fluid accumulation, and death within a few hours. ${ }^{23}$ Toxicologists called it an "inner drowning" of the lungs Klee (1997, 269). Retaliating in June 1916, the Allies employed phosgene with devastating effect during the battles of the Somme; by firing 4000 gas-filled shells

\footnotetext{
${ }^{19}$ TNA, WO188/802, pp. 3, 10f; for Crossley see TNA, WO142/264, Lt Col A.W. Crossley RE, "The Royal Engineers Experimental Station, Porton" (1919).

${ }^{20}$ TNA, WO188/802, p. 10; McCamley $(2006,97)$.

${ }^{21}$ TNA, WO188/802, p. 20.

${ }^{22}$ Mustard gas, or dichlorodiethyl sulphide, was code-named 'H' or 'HS'. Lewisite, or chlorovinyl dichloroarsine, was code-named ' $L$ '. For the exact chemical names of the code-named warfare agents see Historical Survey $(2006,209)$.

${ }^{23}$ For the properties of phosgene as a chemical warfare agent see Marrs et al. (1996, 185-202).
} 
simultaneously, and thus releasing a total of 54 tons of gas over the target area, the Allies wiped out hundreds, if not thousands, of German soldiers, horses, and wild animals.

The close proximity of Porton's laboratories to one another allowed scientists and service officers to conduct integrated research across disciplinary boundaries. Except for a few scientists who wanted to protect their academic independence, most researchers were given military ranks. ${ }^{24}$ Physiologists, chemists, pathologists, meteorologists, and a range of technical and military experts all collaborated in designing and executing experiments, both outdoors on the test range and indoors in the laboratory, sampling station, or gas chamber; by sharing their research data, they managed to improve protective clothing, diagnostic tools, and forms of treatment. Sometimes, relevant expertise had to be brought in from the outside. Porton's first respirator and gas tests, for instance, were conducted by civilian rescue workers from Derbyshire, where mining accidents from gas explosions were not uncommon (McCamley 2006, 97). Teamwork was an essential ingredient of Porton's developing research culture. It provided scientists and military personnel with an incentive to join the establishment and work long, exhausting hours, late at night, or during weekends. Porton's collaborative "spirit and unity of purpose," as Crossley put it, strengthened their belief that they belonged to an exclusive group of professionals who were tasked by the government to develop chemical weapon technologies. $^{25}$

New challenges brought about by modern chemical warfare also led to advances at Porton in defensive technologies for both soldiers and civilians, for example in the design and development of more efficient respirators (Sturdy 1998). Realizing that Allied respirators offered improved protection against certain gases, chlorine and phosgene especially, German scientists developed ever more lethal and incapacitating agents that attacked the body from the outside. Dichlorethyl sulphide, or mustard gas as it became known in Britain because of its distinct garlicky, mustard-like smell, attacked the skin, causing severe burns and blisters within a couple of hours. ${ }^{26}$ If inhaled, mustard gas could cause serious inflammation of the lungs, followed by a slow and painful death from asphyxiation. In Germany, the agent was called "Lost" in recognition of the two scientists (Lommel and Steinkopf) who synthesized it, and in France it was called "Ypérite" in reference to Germany's first mustard gas attack in July 1917, when the military employed the agent to deadly effect in the area around, yet again, the heavily embattled Ypres. The onset of symptoms was delayed, and thousands of soldiers were unaware of having been exposed to a toxic agent, yet developed severe blisters on their hands and neck, and in armpits, groin, and buttocks. The blisters often became infected, leaving soldiers

\footnotetext{
${ }^{24}$ TNA, WO188/802, p. 3; see also Roughton $(1949,320)$.

${ }^{25}$ TNA, WO188/802, p. 8.

${ }^{26}$ Sulphur mustard (mustard gas) was first synthesized in the mid nineteenth century and developed as a chemical warfare agent during the First World War. For the chemical properties of sulphur mustard see Marrs et al. (1996, 139-173).
} 
totally incapacitated and in need of medical treatment. Impregnated leather gloves and suits drenched in linseed oil provided some degree of protection, yet these could be worn only temporarily. British scientists quickly came to realize that the complex scientific problems linked to mustard gas, and the means to protect the human skin from it, needed to be studied in great detail after the end of hostilities. As the "King" or "Queen" of war gases (Tucker 2006, 19; Klee 1997, 269; Groehler 1989, 72), contaminating Allied troops and their equipment for prolonged periods of time, mustard gas stood at the forefront of Porton's research until the end of the Second World War.

\section{Servants of the Realm}

The generation of civilian scientists and service officers associated with Porton during the Great War had grown up in Victorian and Edwardian Britain, came from middle-class or more modest social backgrounds, studied at elite universities such as Cambridge, Oxford, or University College London, and occasionally married into the British establishment. Porton's origin as a defense establishment during the Great War was intricately connected with a generation of male researchers who were driven by a deep-seated desire for advancement and social prestige, an emerging "intellectual aristocracy" with strong social and professional bonds, determined to unlock the secrets of the world through science and experiment and thus realize their visionary ideas of modern society (see also Sturdy 2011). Those who believed in the power of science were men such as Lieutenant Colonel Charles Lovatt Evans (1884-1968) who, according to a friend, "possessed the great qualities of some of the most zealous and distinguished of the Victorians, who accomplished their life's work by an immense capacity for hard work and a burning zeal for achievement."27 At Porton, Lovatt Evans' colleagues included the Cambridge physiologist Joseph Barcroft. Despite his Quaker upbringing, Barcroft felt the need to contribute to the war effort after Germany's premeditated gas attack.

In January 1917, prompted by the devastating effects of Germany's mustard gas attack, Porton established a permanent laboratory for physiological tests on humans at nearby Boscombe Down Farm. ${ }^{28}$ The department seems to have been limited at first to a single hut, measuring 30 feet by 15 feet, which was converted into an office and physiological laboratory. To ensure close liaison with the Royal Army Medical Corps (RAMC), medical officers were attached to Porton. ${ }^{29}$ Conditions were

\footnotetext{
${ }^{27} B M J$, Obituary, Charles Lovatt Evans, 3 (1968), 5619, pp. 684-685.

${ }^{28}$ The decision was taken by the Chemical Advisory Committee under Barcroft's leadership: TNA, WO142/264, Lt Col A.W. Crossley RE, "The Royal Engineers Experimental Station, Porton" (1919), pp. 11ff; also TNA, WO188/802, p. 7; Sturdy (1998, 70).

${ }^{29}$ During the First World War, Rudolph Peters worked as the medical officer under A.E. Kent, who was in charge of offensive chemical warfare on sections of the front controlled by the British First Army; TNA, WO188/802, p. 7.
} 
austere, to say the least, with Peters not only living in the hut but taking his bath in a round tin on the floor of the post-mortem room where the animals were dissected (Thompson and Ogston 1983, 499). Other accounts mention a better-equipped outfit: an old brick building, laboratories, offices, and even a gas chamber for various animal experiments (Garner 2003, 138). Whether staff deliberately played down the existing working conditions to highlight their scientific achievements is difficult to tell in retrospect, yet what seems to be certain is that facilities were relatively simple, even by the standards of the day. Under Barcroft's leadership, and in collaboration with British universities, for example with Cambridge's Chemistry Department, itself engaged in the preparation of toxic agents under the leadership of Sir William Jackson Pope (1870-1939), these men set out to investigate the effects of chlorine, phosgene, adamsite (DM), an arsenical irritant, and mustard gas in experimental gas chambers and to analyze the results in improvised laboratories. ${ }^{30}$

Research had at first concentrated on assessing toxic agents for their ability to kill within forty-eight hours, though experts soon discovered the "casualty producing effects" of certain gases. Chemical warfare, they realized, was not so much about killing people but about incapacitating them for the duration of combat activity. Toxicity trials had revealed that the length of exposure to certain substances, and their concentration, were key in determining the degree to which agents were harmless or dangerous. By the end of the war, Barcroft's team had examined the toxicity and the possible remedies for 160 substances, including mustard gas and lewisite, which became known among Allied propagandists as the "dew of death," a description that overemphasized its actual killing potential. ${ }^{31}$

Although Porton encountered difficulties in retaining some of the civilian scientists after the war, with men such as Barcroft, Lovatt Evans, and Starling returning to their university positions, often as FRS, almost all of them continued to conduct research which was informed by their work on chemical warfare. ${ }^{32}$ In the interwar period, and thereafter, the "Old Portonians" formed a closely knit group of experimental scientists who continued to have close links to the British defense community at Porton Down. ${ }^{33}$ This was the generation of military men and civilian researchers for whom the experience of the Great War, and of tens of thousands of gassed soldiers, marked a watershed in their determination to prepare the country

\footnotetext{
${ }^{30}$ TNA, WO188/802, p. 15; see also Gibson (1941, 321f.); for Pope see also IWM, Photographic Collection, Portrait W. J. Pope (1870-1939).

${ }^{31}$ For a history of lewisite see Vilensky (2005).

${ }^{32}$ For Lovatt Evans' subsequent professional career see WL, PP/CLE/A.9, Jodrell Chair; PP/CLE/ A.11, Service at Porton Experimental Station, Wiltshire, during the Second World War. Miscellaneous Correspondence re. Secondment and Service. For Barcroft's postwar career as a Reader in Physiology at Cambridge University see Roughton (1949). During the early 1920 s, Peters worked with F.G. Hopkins, Malcolm Dixon, and J.B.S. Haldane at the Balfour Laboratory at Cambridge University; see Peters (1959).

${ }^{33} \mathrm{Lt}$ (later Maj) J.A. Sadd continued work as a senior civilian scientist at Porton until the $1950 \mathrm{~s}$. Lt Col W.A. Salt, Lt Col A.E. Kent, Capt S.J. Steadman, and Lt A.C. Peacock all worked at Porton Down after the Great War.
} 
for a future war, protect the army and civilians from the anticipated fallout, and supply the military with the means and methods to retaliate. On the eve of the Second World War, many of those who had fought in the previous war were ready to recommence research on chemical warfare to protect the United Kingdom and her allies.

\section{Crisis of Legitimacy}

Following the Armistice in November 1918, the victorious powers envisaged the creation of a demilitarized and largely peaceful world, free from violence and weapons of mass destruction. Undermined by feelings of revenge and demands for reparations, their vision got off to a difficult start. Under the Versailles Treaty, notorious for its humiliating terms, the Allies not only annexed territory, disarmed the German army, and extracted material resources from a traumatized, politically divided society that was barely coming to terms with military defeat, but also forced the government to admit sole responsibility for the war (Kershaw 1998, 136). To destroy any future chemical warfare capability, Germany was strictly prohibited, under Article 171, from using, producing, or importing chemical agents, including "asphyxiating, poisonous or other gases and all analogous liquids." 34

Although far from homogenous, public opinion became a powerful force in shaping the international community's protracted disarmament negotiations. ${ }^{35}$ In 1918, representatives of the British medical profession called for a ban on chemical warfare in The Times, describing it as an "unclean," uncontrollable, and malignant weapon of war which ought to be abolished. ${ }^{36}$ Elsewhere, doctors and nurses employed by the armed forces protested against their involvement in this type of warfare. Some have argued that the interwar debate simply resulted from a "clash" between the wartime practicalities of using chemical weapons and the experienced or perceived horrors among "victims and observers alike," but this overlooks quite specific economic, political, and scientific factors as well as cultural traditions that shaped the discourse at a national level (see Van Bergen 2012). In the United States, where the chemical industries, like their British counterparts, launched a major publicity offensive, chemical warfare became a matter of domestic politics. Chemical warfare meant big business at a time of great economic uncertainty and guaranteed the employment of thousands of officers lecturing in US chemical

\footnotetext{
34“"The use of asphyxiating, poisonous or other gases and all analogous liquids, materials or devices being prohibited, their manufacture and importation are strictly forbidden in Germany" (Treaty of Versailles, Article 171). Tucker (2006, 21); Hobbs et al. (2007, 278f.). Britain's proposal during the Versailles Treaty negotiations for full disclosure of Germany's wartime manufacturing processes was seen as an attempt at economic espionage, and rejected by the United States; see also SIPRI (1971, 235f.).

${ }^{35}$ See SIPRI (1971, 231-267), Chap. 3: "Popular Attitudes towards CBW”, 1919-1939.

${ }^{36}$ The Times, 29 November 1918, p. 6.
} 
warfare $(\mathrm{CW})$ training facilities. ${ }^{37}$ In a bid to improve chemical warfare preparedness and secure the postwar continuity of the Chemical Warfare Service (CWS), founded in mid 1918, stakeholders and major suppliers from the building, mining, and engineering trades, who advocated a more isolationist policy, became involved in a campaign to frustrate international disarmament negotiations. The proposed abolition of the CWS, in particular, threatened the existence of small, specialized companies supplying the US chemical warfare industry, which needed to adjust to peacetime conditions, for example through the sale of tear gas to law enforcement agencies. While Edgewood Arsenal highlighted the "relative humaneness" of toxic agents compared to high explosives in specially designed publications, engineering firms promoted their latest airtight steel tanks. Elsewhere, the producers of metal ores advertised their ability to deliver "gas by the ton." 38

Yet the campaign also fuelled public anxieties against possible airborne attacks with toxic agents, and strengthened the resolve of organizations such as the British Association for the Advancement of Science and the International Committee of the Red Cross (ICRC) to protest against the use of poison gas in 1918 and call for an absolute ban on chemical warfare (SIPRI 1971, 239-242; Hobbs et al. 2007, 280; Van Bergen 2012). Having been criticized by the belligerents for abandoning its principle of impartiality, the ICRC subsequently took a more "neutral" position and "waged war on gas warfare" by campaigning for the improvement of defensive capabilities in the late 1920 s in order to make the use of chemical warfare agents unworkable; there was even an ICRC-funded prize for innovative developments in the field of chemical defense. Anti-militarist groups and pacifists, however, became increasingly hostile towards the ICRC for viewing chemical weapons as an inevitable reality of future wars. In the aftermath of the Second World War, and in light of the Holocaust, the ICRC's stated policy of impartiality and non-interference became the subject of heated controversy, which has continued ever since.

Another major organization involved in shaping public opinion on the subject of chemical and biological warfare was the League of Nations. In the 1920s, it played a leading role in negotiating international agreements for the limitation and reduction of chemical weapons, and in prohibiting their use in future wars. Founded in 1920, the League of Nations was firmly committed to comprehensive disarmament, weapons control, and conflict resolution through international cooperation. Yet political setbacks during the League's formative years placed the United States in a powerful negotiating position. Held in Washington DC from November 1921 to February 1922, the Conference on the Limitation of Armament, organized by the United States to establish a new security framework in the Pacific area, sought, inter alia, a legally binding resolution for the prohibition of chemical weapons. During the negotiations, because of behind-the-scenes tensions between experts and

\footnotetext{
${ }^{37}$ CHF, Archive Collection, GB98.09, Williams-Miles Reprint Collection, William Williams, Notebook: US Gas School, 1918.

${ }^{38} \mathrm{CHF}$, The Edgewood Arsenal, Special Edition of Chemical Warfare, vol. 1, no. 5 (March 1919); for the origins of the CWS see Brophy and Fisher (1959); Ede (2011).
} 
politicians about the real and imagined power of chemical agents and the ability to control them, careful management was required to preserve a united front (SIPRI 1971, 242ff.). Article 5 of the Washington Agreement prohibited the "use in war of asphyxiating, poisonous or other gases, and all analogous liquids, or materials, of devices," such use having been "justly condemned by the general opinion of the civilized world." "39 Despite reservations by Britain and France, which prevented the resolution from coming into force, the Washington Agreement marked an important milestone that galvanized public opinion and political power to work towards an international chemical weapons ban. ${ }^{40}$

Clearly affected by the international climate, Porton Down suffered a crisis of legitimacy after it transpired that Britain's chemical warfare program no longer enjoyed unconditional political and public support. ${ }^{41}$ At first, almost all research activities ceased. Parliamentary questions were now being raised about Porton's annual cost to the taxpayer. ${ }^{42}$ Reflecting public concerns about a substantially weakened economy, the MP Hugh Morrison queried in 1920 whether the government would not be well advised to "have it [Porton] closed down." In his cautious reply, which avoided revealing that the total cost of the establishment had been around $£ 90,000$ in $1919-1920,{ }^{43}$ Winston Churchill told the House of Commons that the government aimed to keep the experimental facility open "until the attitude of the League of Nations to chemical warfare is defined." 44 In March 1922, prompted by the Washington Agreement, the government came under renewed pressure, but insisted that it "would be failing in its duty if it failed to take all possible steps which might be necessary to protect the Forces of the Crown and the inhabitants of the country against gas attacks in time of war."45

\footnotetext{
${ }^{39}$ Article 5 of the Washington Agreement stated: "The use in war of asphyxiating, poisonous or other gases, and all analogous liquids, or materials, of devices, having been justly condemned by the general opinion of the civilized world, and a prohibition of such use having been declared in treaties to which a majority of the civilized powers are parties; now to the end that this prohibition shall be universally accepted as a part of international law, binding alike the conscience and practice of nations, the signatory powers declare their assent to such prohibition, agree to be bound thereby between themselves, and invite all other civilized nations to adhere thereto." See https:// ihl-databases.icrc.org/applic/ihl/ihl-search.nsf/content.xsp.

${ }^{40}$ Whereas the British representative pointed out that it is "impossible to prevent a nation bent upon Chemical Warfare from making preparations in peacetime, no matter what the rules of war may be," the French Government reserved the right "to act in accordance with the circumstances" if an enemy refused to give a guarantee not "to use poison gas"; TNA, WO188/802, p. 48; Tucker (2006, 21); Hobbs et al. (2007, 280).

${ }^{41}$ Subordinated to the Chemical Warfare Department, Porton shared responsibility for chemical warfare research with a number of supervisory committees and organizations, including the Chemical Warfare Committee and university research facilities.

${ }^{42}$ Hansard, HC Debate, vol. 122 c60 W, Experimental Ground, Porton, 1 December 1919.

${ }^{43}$ For the total cost of Porton Down between 1919 and 1924 see Hansard, HC Debate, vol. 181 c1108, Chemical Warfare Research Department, 10 March 1925.

${ }^{44}$ Hansard, HC Debate, vol. 130 c1063, Chemical Experimental Ground, 15 June 1920.

${ }^{45}$ Hansard, HC Debate, vol. 152 c984 W, Asphyxiating Gas (Washington Treaty), 27 March 1922.
} 
Unbeknown to the public, the Cabinet had accepted the recommendations of the Holland Committee in May 1920 to expedite chemical warfare research and reorganize Porton Down. Made up of experienced military and civilian experts, the committee had concluded that the "safety of the Empire" could not be left to chance: "A nation which is unprepared for gas warfare lays itself open to sudden and irretrievable disaster." 46 Separating defensive from offensive research was seen to be impossible, because one could not be understood without the other. Recommended changes to the organization involved a reconstituted Chemical Warfare Committee, the attachment of experts to the Director of Military Intelligence, the consolidation of "research, design and supply" under the control of the Ministry of Supply, and improved liaison between Porton's scientists and the armed services, a subject which had caused some considerable controversy during the war. ${ }^{47}$ It was recommended that Porton's staff should, in future, be composed "partly of soldiers and partly of men of science," the latter to be of "high standing" and "independent of outside inspection and criticism." 48 To attract scientists of the highest caliber, and because staff sacrificed parts of their careers and occasionally risked their own health in the pursuit of knowledge, the authorities were asked to offer substantial inducements in the form of salaries, security of tenure, pensions, and the right to publish. ${ }^{49}$ Largely oblivious to stringent cuts to the military budget during a period of economic austerity, the committee weighed Porton's “considerable" running costs on the basis of national security considerations. It also believed that Porton's discoveries were likely to have scientific and commercial value that would transform the organization into a "very valuable national asset."

At the same time military interference with Porton's activities needed to be kept to a minimum, provided the General Staff could "indicate the general lines" which appeared to be the most promising. The tension between the ability to conduct independent research, free from external pressures, and the practical demands by the military to defend the country against potential chemical warfare attacks, together with the need for a credible retaliatory capability, have characterized Porton ever since.

Close liaison between Porton's scientists and expert networks elsewhere in Britain and overseas, essential in maintaining a first-class research facility, was to be assured through the Chemical Warfare Committee, which was broadly

\footnotetext{
${ }^{46}$ UoK, Porton Archive, A207, "Report of the Committee on Chemical Warfare Organization", 7 July 1919, p. 5; also TNA, WO188/802, p. 30.

${ }^{47}$ Subordinating field trials to the military requirements of war had, according to some, slowed down, if not inhibited, Britain's chemical warfare program during the Great War; UoK, Porton Archive, A207, 'Report of the Committee on Chemical Warfare Organization', 7 July 1919, pp. 3ff; TNA, WO188/802, pp. 13, 17.

${ }^{48}$ UoK, Porton Archive, A207, "Report of the Committee on Chemical Warfare Organization", 7 July 1919 , p. 5.

${ }^{49}$ UoK, Porton Archive, A207, "Report of the Committee on Chemical Warfare Organization", 7 July 1919, p. 5; TNA, WO188/802, pp. 30f.
} 
representative of the wider scientific, military, and business community. ${ }^{50}$ To ensure the coordinated production of toxic agents, including those for testing purposes at Porton, the committee recommended the creation of a state-controlled factory for chemical warfare products at Sutton Oak, near St Helens in Lancashire, which later became the Chemical Defence Research Establishment (see Carter and Pearson 1996, 60f; Carter 2000, 52f.) A representative of Porton liaised with members of the committee about planned field trials. It was this coordinated approach to chemical warfare through an external body of experts and stakeholders that other nations, the United States and Canada especially, began to emulate.

\section{Collaboration}

On a bilateral level, Britain and the United States joined forces in developing offensive and defensive chemical warfare capabilities that required the sharing of information and resources. In 1918, after the American Expeditionary Force (AEF) sustained disproportionately high numbers of chemical warfare casualties due to an inadequate level of preparedness, the US Army attached liaison officers to Porton to keep abreast of Britain's advances in chemical warfare work, a tradition which continued thereafter. ${ }^{51}$ Britain's scientists, on the other hand, developed close links with their counterparts at Edgewood Arsenal, near Baltimore, Maryland, which became the United States' headquarters for chemical warfare research and development (Chemical Corps Association 1948, 14ff.). Given the exclusivity of the field, together with the need to preserve the utmost secrecy, research networks which had been established during and after the First World War were central in creating a long-term system of bilateral, and later tripartite, cooperation on chemical warfare between the Allied powers.

Still unresolved questions about the legitimacy of chemical warfare, together with the widespread condemnation of toxic agents as a means of warfare, turned intelligence sharing between Britain and the United States into a sensitive issue requiring a clear understanding about confidentiality arrangements and levels of secrecy. By assigning the highest security classification to chemical and biological warfare matters, and by avoiding the publication of details that could inform other

\footnotetext{
${ }^{50}$ In 1920, members of the Chemical Warfare Committee included: Joseph Barcroft (professor of physiology, Cambridge University), A.W. Crossley (former Commandant Porton and Director of the Cotton Industry Research Association), C.G. Douglas (physiologist, Oxford), Harold Hartley (chemist, Oxford), H. Levinstein (representative of Levinstein Limited, chemical manufacturers), Sir William Pope (professor of chemistry, Cambridge University), Jocelyn F. Thorpe (professor of organic chemistry at Imperial College and representative of the Department of Scientific and Industrial Research), A.M. Tyndall (professor of physics, Bristol University); see TNA, WO188/ 802, pp. 32ff.

${ }^{51}$ TNA, WO188/802, p. 11.
} 
countries about the nature and extent of the work undertaken, Britain attempted to ensure that its expanding chemical warfare program would not become public knowledge. $^{52}$

In addition, Britain was outsourcing certain types of research, some of it offensive in nature, to British-controlled laboratories overseas to deflect public attention from its expanding chemical warfare program. ${ }^{53}$ Subsidiary research facilities in India and Australia, established in the 1920s, allowed British scientists to investigate the effect of chemical warfare agents under specific climatic conditions and among different population groups. Between 1921 and 1924, one of Porton's officers, Lieutenant Colonel W.A. Salt, ran the Military Chemical Laboratory in Dehra Dun in India, which conducted high-altitude and smoke trials to test different types of respirators suitable for bearded Sikhs. ${ }^{54}$ Porton's service personnel and physiological staff also served as instructors to the Indian Chemical Warfare School in Begaum, a center of the armed forces for the British Raj. In 1929, the British authorities set up a Chemical Warfare Research Establishment in Rawalpindi, in the Punjab, staffed by scientists and officers from Porton, who engaged in smoke trials for the protection of bridges and other strategic sites. ${ }^{55}$ To forge better relations, Indian representatives were invited to Britain for an appreciation of the power of chemical warfare. Around the same time, Britain established closer links with the Australian Chemical Warfare Board to study the effects of tropical and subtropical conditions on chemical warfare, attached Australian, Canadian, and South African representatives to Porton, and organized chemical warfare courses in the Dominions. In some cases, Porton helped Allied governments to deal with civil unrest by providing defensive technologies and chemical agents; in 1930, for example, Porton supplied South Africa with specially developed bombs filled with tear gas which the government employed against opposition groups. Most of Porton's activities overseas were strictly classified, not only to protect existing expertise but also to preserve Britain's political credibility in ongoing disarmament talks. At an international level, though, and in public, the subject of chemical warfare was openly discussed. ${ }^{56}$

\footnotetext{
${ }^{52}$ UoK, Porton Archive, A205, Porton Experiments 1920 s, Atkisson to Chief of CWS, Washington, 15 July 1924.

${ }^{53}$ TNA, WO188/802, pp. 86-90.

${ }^{54}$ TNA, WO188/802, pp. 86ff.

${ }^{55}$ TNA, WO188/802, p. 88; see also Evans (2007).

${ }^{56} \mathrm{~A}$ pamphlet published by the League of Nations noted that "everywhere except Germany, experiments in Chemical Warfare openly proceed [...]. It will not necessarily inflict more pain than high explosive, but will tend to aggravate the burden of war upon the civilian population"; TNA, WO188/802, p. 49.
} 


\section{The Geneva Protocol}

The "Protocol for the Prohibition of the Use in War of Asphyxiating, Poisonous or other Gases and of Bacteriological Methods of Warfare," known as the Geneva Protocol, and modeled on Article 5 of the Washington Agreement, outlawed the employment of chemical and biological weapons. However, it failed to establish an international verification and enforcement system, and exposed deep-seated disagreements about disarmament. The United States was opposed to prohibiting the use of tear gas in war on the grounds that it was also used by police forces against civilians in peacetime, especially as a weapon for riot control, and they refused to ratify the Protocol until 1975. The French and the British were likewise reluctant to go ahead and ratify, and this further limited the scope of the Protocol to a "no-first-use" agreement (Hobbs et al. 2007, 286f.). ${ }^{57}$

Questions relating to chemical and bacteriological weapons routinely surfaced in the discussions of the Preparatory Commission for the World Disarmament Conference $^{58}$ that opened under the chairmanship of the former British Foreign Secretary and Labour politician Arthur Henderson (1863-1935) in Geneva in February 1932. Preliminary meetings had highlighted the relative ease with which a chemical industry could be adapted to the production of toxic agents, and their potential delivery from the air. Secret intelligence further suggested that almost all countries that had signed up to the Geneva Protocol were pursuing an offensive chemical weapons capability. ${ }^{59}$ It therefore came as little surprise that the negotiations were beset by disagreements over what constituted "offensive" and "defensive" weapons and by Germany's belligerent posturing. Britain's high-profile role during the negotiations left senior officials back in London distinctly nervous about granting permission for human experiments involving chemical warfare agents. By the time Britain proposed a draft convention at the World Disarmament Conference in March 1933, two months after Hitler's accession as Reich Chancellor, it had become clear that Europe, if not the world, was faced with an extraordinarily brutal military dictatorship which had no intention of settling international disputes by peaceful means. The talks collapsed after Germany withdrew firstly from the Geneva World Disarmament Conference and then, in October 1933, from the League of Nations. Breathing tests with toxic substances remained prohibited until the outbreak of war in 1939 changed the ethics of human experimentation at Porton.

Whereas some have hailed the Geneva Protocol as "the high-water mark of the hostility of public opinion towards CW," others have stressed the role of the international community in reasserting its authority after the contravention of The

\footnotetext{
${ }^{57}$ See also Hobbs et al. $(2007,255-295)$. For the use of tear gas in dealing with civil disturbances in the United States see SIPRI $(1971,270)$.

${ }^{58}$ The title of the conference was "Conference for the Reduction and Limitation of Armaments." ${ }^{59}$ TNA, WO188/802, p. 49; see also the debate in parliament about Britain's "offensive" and "defensive" chemical warfare capability; Hansard, HC Debate, vol. 272 cc811-12, Chemical Warfare, 30 November 1932.
} 
Hague Declaration during the First World War (SIPRI 1971, 247; Hobbs et al. 2007, 287ff.). Irrespective of whether chemical weapons had been "politicized" before, during, or after the war, whether politicians had responded to public opinion, or whether chemical weapons themselves were inhumane and immoral, the Geneva Protocol established a new international law which not only prohibited the use of chemical and biological weapons, but which, perhaps more importantly, most nations perceived to be obligatory.

\section{Foreboding}

Far from being a "sudden outburst" of idealism, the Geneva Protocol was the League's "attempt to meet a grave and increasing practical danger, viz., the insecurity of European peace and, resulting therefrom, the rise of a new competition in armaments" (Hobbs et al. 2007, 288f.). ${ }^{60}$ In the context of emerging European dictatorships, this constituted a realistic assessment. Since the early 1920s, the German Reichswehr and the Soviet Red Army had been involved in clandestine military operations that included weapons development and arms trade. Although the manufacture of chemical weapons was banned under the Versailles Treaty, and outlawed by national legislation, Germany's chemical industry and the military were organizing shipments of poison gas from Soviet Russia. The accidental release of phosgene from a storage tank in Hamburg in 1928 alerted the international community to the fact that Germany was flouting the Versailles Treaty. By the early 1930s, Germany's rearmament program had reached such alarming proportions that another war in Europe seemed a realistic possibility, especially in the context of a Hitler-led regime.

In the context of the Europe-wide rearmament programs that preceded the outbreak of the Second World War, issues relating to chemical warfare became absorbed into debates about national security. Almost all European governments, including the Soviet Union and Britain, employed the threat of chemical weapons as a way of accelerating the introduction of comprehensive civil defense measures. Whereas Soviet citizens received anti-gas drills in simulated gas attacks on Leningrad and Kiev in 1928, the British public was exposed to exaggerated reports about the power of chemical weapons. One estimate predicted that all men, women, and children in Central London would be killed if a large poison gas bomb were dropped onto Piccadilly Circus; another estimated the death of all Londoners if 40 tons of newly developed toxic agents were released. Italy's widely reported, but at first vehemently denied, use of chemical weapons in Ethiopia in 1935 and 1936, which involved the alleged use of mustard gas bombs against civilians and hospital patients, led to demands for sanctions by the League of Nations and increased the

\footnotetext{
${ }^{60}$ See also TNA, PRO30/69/1273, "Some Questions on the Geneva Protocol” (1925).
} 
value of chemical weapons as a propaganda tool among anti-fascist groups. ${ }^{61}$ In the Middle East, the British government pursued a dual strategy of attempting to broker a political settlement in conjunction with providing practical support; Porton's experimental officer was dispatched to Egypt, Aden, the Sudan, and Palestine to advise military officials about defensive chemical warfare technologies. ${ }^{62}$ The outbreak of the Spanish Civil War in 1936 led to a fierce propaganda war over chemical warfare, with insurgents and government forces each alleging the enemy's use of poison gas. In the context of Britain's appeasement policy, official support was limited to public condemnation and the supply of respirators to aid the Spanish government. Although the Spanish military had shown few moral qualms in employing chemical weapons against Moroccans in the mid 1920s, reports confirming the use of chemical agents during the Spanish Civil War never materialized, apart from one incident involving the alleged use of tear gas (SIPRI 1971, 258ff.; Balfour 2002, 123-156). At the same time, intelligence from Germany and the Soviet Union suggested increased chemical and biological warfare activities. ${ }^{63}$

Retaliatory preparations were likewise set in train. In 1936, in addition to existing facilities which produced 20 tons of mustard gas per week, the Committee of Imperial Defence ordered the development of a pilot plant with an estimated output of 50 tons per week for the production of a new chemical warfare agent, code-named HT, better known as Runcol. ${ }^{64}$ Less than a year later, over 5 million respirators were reported to be in storage for a national emergency. Additional storage facilities for defensive equipment were set up in Canada and South Africa. ${ }^{65}$ Following the notorious Munich Agreement of September 1938, and Hitler's invasion of what was left of Czechoslovakia in March 1939, the government distributed over 30 million respirators. Two years into the war, Britain had at its disposal a total of almost 4 million children's respirators and anti-gas helmets alone (Grayzel 2012, 250; Harris and Paxman 1982, 107f.). ${ }^{66}$ Here was an aggressor who warranted the mobilization of all resources in preparation for a potential chemical warfare attack.

Shortly before the outbreak of war, research on chemical and biological warfare accelerated at all levels. Through liaison with the ARP Subcommittee, Porton became an integral part of Britain's civil defense planning with increased access to military intelligence and hardware. ${ }^{67}$ In 1935, an RAF "Special Duty Flight" was put on permanent stand-by to allow scientists to study the effects of airborne gas

\footnotetext{
${ }^{61}$ TNA, WO188/802, p. 51; Grayzel (2012, 181f.).

${ }^{62}$ TNA, WO188/802, p. 89.

${ }^{63}$ TNA, WO188/802, p. 51; see also Balmer (2001).

${ }^{64}$ TNA, CAB4/24, Committee of Imperial Defence, "Policy with Regard to the Possible Use of Gas as a Retaliatory Measure in War", 8 July 1936; also Historical Survey (2006, 209).

${ }^{65}$ TNA, WO188/802, p. 89.

${ }^{66}$ Sources have recently come to light, however, which suggest that the majority of gas masks produced for civilians and service personnel contained significant amounts of asbestos; see Schmidt (2015, 69ff.).

${ }^{67}$ TNA, WO188/802, p. 44.
} 
attacks on the Porton range (ibid.). Research and development at Porton included the design of respirators for humans and animals, detector and decontamination devices, filtration units for ships, buildings (including air raid shelters) and armored vehicles, methods to prevent toxic gas from infiltrating the London Underground and government buildings, impregnated garments to protect against specific agents, and the testing of anti-gas ointments. To assist the RAF in assessing wind conditions on the ground or the Royal Navy in battleship protection, Porton conducted research on smoke, including smoke curtain installations and assessments about the relation between screening effects and meteorological conditions. ${ }^{68}$ Offensive work involved chemical shell and aircraft gas bombs, ground mustard gas bombs to contaminate whole areas, gas-filled rocket launchers, gas-spraying devices, toxic smoke (arsenical) weapons, or substitute agents ("pseudo gases") to mislead the enemy. ${ }^{69}$ Hand in hand with the rapid expansion of Porton's areas of responsibilities in the interwar period came the expansion of its research staff, who forged closer links with subsidiary research facilities in India and later Canada. ${ }^{70}$ The number of scientists affiliated with Porton during these years is testimony to the way in which the government managed to integrate research and development into the planning process for future military operations (McCamley 2006, 100).

By the late 1920s, the notion of gas warfare and its associated imagery had become a powerful part of the collective memory of the European public. This applied especially to First World War memorials. Built in 1929 on Belgian soil to commemorate the suffering of thousands of victims of asphyxiation in the first chemical attack in modern history, the Steenstraate gas memorial blamed the German military for this act of inhumanity, which is why the occupying German forces duly destroyed it in 1941 (Jacobs 1996, 46-48; see also Goebel and Connelly 2017, forthcoming).

\section{Ethical Relativism}

At the start of hostilities, Britain, France, and Germany pledged to abide by the Geneva Protocol, yet none of the parties trusted that the agreement would be observed "a moment longer than is necessary" (Harris and Paxman 1982, 83, 107). Britain anticipated the use of chemical weapons by one or more of the belligerents.

\footnotetext{
${ }^{68}$ That smoke could be used as an effective weapon of war had been recognized as early as April 1915, days before Germany's first gas attack, when Winston Churchill as the First Lord of the Admiralty had commissioned a number of "wonderful smoke-making experiments"; Churchill (1923, 84f.); also Carter (2000, 53f.).

${ }^{69}$ TNA, WO188/802, pp. 53-66.

${ }^{70}$ Whereas the scientific staff had risen from 23 to 51 between 1922 and 1925, it had more than doubled to 120 by 1936/37. By 1938, Porton had a total of 152 researchers working on all aspects of defensive and offensive chemical warfare. The annual "Dominion Day" event, for example, organized by Porton between 1937 and 1942, offered visitors insight into Porton's research and development program; TNA, WO188/802, pp. 41, 89.
} 
Millions of leaflets were distributed to all households and the BBC was on stand-by to broadcast pre-arranged gas warnings in the event of gas attacks. Following Hitler's Blitzkrieg campaign through the Low Countries and the surrender of France in May 1940, the threat of invasion by German forces loomed large in the minds of British officials in London.

By 1944, four years into an extraordinarily brutal and costly war, Allied military planners were growing increasingly concerned about the potential use of chemical agents by Axis forces, fearing the employment of these weapons in a desperate, last-ditch attempt to hold their positions. The large-scale decommissioning of scientific experts, who began to return to their prewar posts, added to a renewed crisis at military headquarters. Military planners warned about a lack of vigilance and the scaling down of chemical warfare preparedness which could cost Allied forces dearly in the closing stages of the war. At Porton, and elsewhere, researchers were likewise determined to finish the job at hand. ${ }^{71}$

At the same time, the authorities continued incessantly to prepare servicemen and civilians for the Allied invasion which might involve or trigger the use of gas warfare. In May, Porton carried out large-scale chemical warfare exercises in conjunction with beach-head operations by service and civilian authorities; at around the same time, scientists from Porton came to the conclusion that the use of mustard gas was likely to have a "big potential in the subjugation" of Japanese forces on the Pacific islands thousands of miles to the east. ${ }^{72}$ With millions of soldiers and civilians killed and injured, families and children displaced, buildings burnt, and entire cities destroyed, there was little appetite among senior Allied officials to uphold standards of medical ethics and international morality if the end of combat operations would be delayed as a result. Mustard gas and phosgene were Churchill's chemical weapons of choice to attack deep within the German heartland and cause maximum casualties and mayhem, but also as weapons which could legitimately be deployed to defend Britain's beaches, ports and industry against an invading army. His retrospective assessment, made after the war, was that the Germans "would have used terror, and we were prepared to go all lengths" (Harris and Paxman 1982, 110; also Parker 1996, 49).

On 6 July 1944, one month after the D-Day landing of Allied forces in Normandy, Churchill returned once again to the subject by telling the House of Commons that the introduction of the German "flying bomb" raised some "grave questions" about the future conduct of the war. On the same day, dissatisfied by the negative assessment of the Joint Planning Staff (JPS) on the use of gas warfare as a retaliatory measure, he informed his Chiefs of Staff of his intention to employ chemical weapons if it were a matter of "life or death" for Britain or if it would shorten the war by a year:

It may be several weeks or even months before I shall ask you to drench Germany with poison gas, and if we do it, let us do it one hundred per cent. In the meanwhile, I want the

\footnotetext{
${ }^{71}$ WL, PP/CLE/A.11, Lovatt Evans papers, Hill to Lovatt Evans, 24 April 1944; Lovatt Evans to Hill, 27 April 1944.

${ }^{72}$ TNA, WO188/802, p. 112.
} 
matter studied in cold blood by sensible people and not by that particular set of psalm-singing uniformed defeatists which one runs across now here now there. Pray address yourself to this. It is a big thing and can only be discarded for a big reason. I shall of course have to square Uncle Joe [Joseph Stalin] and the President [Franklin D. Roosevelt], but you need not bring this into your calculations at the present time. Just try to find out what it is like on its merits. ${ }^{73}$

Churchill considered it to be "absurd" to worry about the "morality on this topic" since all parties had used chemical weapons during the First World War. Whereas the bombing of large cities had formerly been regarded as a war crime, it was now done by the Axis and Allied forces on a day-to-day basis, he argued. Attempting to downplay any moral concerns of his senior military advisers, he noted: "It is simply a question of fashion changing as she [sic] does between long and short skirts for women" (ibid.). For the Prime Minister, the Geneva Protocol outlawing the use of poison gas was of no relevance if the existence of British realm were at stake.

Although Allied forces appeared to possess the capability, Churchill's senior military advisers stopped short of recommending the start of chemical warfare operations. ${ }^{74}$ The Chiefs of Staff nonetheless expressed a high degree of confidence in respect of the state of Allied readiness to initiate chemical warfare operations. By 1944, British and American stocks located in Britain were deemed sufficient, they said, to produce a "formidable scale of gas attack on Germany during the early and most important phase after a decision has been taken to employ gas."75 Britain alone had produced a total of 40,719 tons of mustard gas and 14,042 tons of phosgene and tear gases during the war (Carter 2000, 53). Instead of a prolonged use of some chemical agents by $20 \%$ of Bomber Command, the Chiefs of Staff recommended the concentration of all British and American long-range bombers in a "massive hammer blow," employing high explosives and phosgene and mustard gas bombs in quick succession on tactical and civilian targets. Phosgene would be dropped on 1000 tactical targets or twenty German cities, causing heavy casualties and deaths among civilians and civil defense personnel. Mustard gas, on the other hand, would be employed against 1500 tactical targets or, alternatively, against sixty specifically identified German cities covering the entire Reich that were "best calculated to bring about a collapse of German morale."76 By causing death and destruction on a monumental scale, military commanders aimed to exercise intense pressure on the regime's leadership, but they were also acutely aware that the population was likely to lack the necessary "initiative required for active revolt" against the Nazi regime following gas attacks (ibid.).

\footnotetext{
${ }^{73}$ TNA, PREM3/89, Personal Minute Churchill to Ismay, 6 July 1944; also Harris and Paxman (1982, 127ff.).

${ }^{74}$ TNA, PREM3/89, "Military Considerations Affecting the Initiation of Chemical and Other Special Forms of Warfare"; Harris and Paxman (1982, 130ff.).

${ }^{75}$ TNA, PREM3/89, "Military Considerations Affecting the Initiation of Chemical and Other Special Forms of Warfare."

${ }^{76}$ TNA, PREM3/89, "Military Considerations Affecting the Initiation of Chemical and Other Special Forms of Warfare."
} 
In France, chemical weapons could aid the war effort by helping Allied forces to "break through the German defences," but they could also slow the military advance, affect communications, unsettle civilian labor, and negatively affect the relationship with the local population. The same was the case in the east, in southern France and in the Mediterranean, where chemical warfare was seen to be counterproductive in maintaining support from civilians and partisans. Existing chemical warfare stocks in the Far East were deemed to be insufficient to allow offensive chemical warfare to be conducted simultaneously in both theatres of war, and defensive measure were inadequate to protect the military from gas under tropical conditions.

Military officials were under no illusion that Germany would immediately retaliate against the United Kingdom, with London as the principal target, if the Allies started to use gas warfare. Although the possible effects of gas on the home front were difficult to judge, they felt that the general public, after five years of war, might be resentful of being exposed to toxic agents if it could be shown that this "could have been avoided." 77 The Chiefs of Staff were also concerned about the effects on public morale of potential retaliatory measures against Allied prisoners of war who might be forced to "work in contaminated areas." 78 All things considered, and irrespective of any political, legal, or moral considerations, Britain's military planners concluded that chemical and biological weapons were not an attractive military proposition. General Hastings Lionel Ismay, one of Churchill's closest military advisers, even suggested to the Prime Minister that the use of these types of weapons was likely to be detrimental to the Allied military campaign:

\begin{abstract}
It is true that we could drench the big German cities with an immeasurably greater weight of gas than the Germans could put down on this country. Other things being equal, this would lead to the conclusion that it would be to our advantage to use the gas weapons. But other things are not equal. There is no reason to believe that the German authorities would have any greater difficulty in holding down the cowed German population, if they were subjected to gas attack, than they have had during the past months of intensive high explosive and incendiary bombings. The same cannot be said for our own people, who are in no such inarticulate condition. ${ }^{79}$
\end{abstract}

However impressive the plans drawn up by the Chiefs of Staff in July 1944 may appear in retrospect, we still need to be careful not to jump to any conclusions, on the basis of the above outlined memorandum, in respect of the actual state of Allied readiness to start chemical warfare operations during the closing stages of the Second World War. Given what we now know about newly developed operational research methods which allowed experts to calculate more precisely the requirements for chemical weapons stockpiles needed for a major military attack, it seems far from certain whether the Allied military would actually have been capable of delivering the kind of "massive hammer blow" to the German enemy within the

\footnotetext{
${ }^{77}$ TNA, PREM3/89, "Military Considerations Affecting the Initiation of Chemical and Other Special Forms of Warfare"; Harris and Paxman (1982, 132).

${ }^{78}$ TNA, PREM3/89, "Military Considerations Affecting the Initiation of Chemical and Other Special Forms of Warfare."

${ }^{79}$ TNA, PREM3/89, Personal Minute, Ismay to Churchill, 28 July 1944.
} 
operational realities of war conceived by the Chiefs of Staff, had the order to employ chemical and biological weapons actually been given. As plans were drawn up in the United States to employ chemical weapons as part of an invasion of the Japanese home islands, for example, it became apparent that the quantitative requirements far exceeded existing stockpiles of chemical munitions. Yet if we assume, for a moment, that the existing chemical weapons stockpiles were likely to be insufficient for the kind of attack the Chiefs of Staff had outlined to Churchillwho at this point seems to have been, by all accounts, keen to launch chemical warfare operations - then this raises a series of questions: whether the Chiefs of Staff were aware of the fact that their chemical warfare capability might not have been quite what it seemed, and if so, why they did not communicate this fact to the Prime Minister. The following scenario is certainly possible: under considerable pressure from Churchill to confirm the viability of employing such unorthodox weapons, which up to this point had not been used in the war, senior military officials - who were keen to keep it that way-might have overstated the Allied chemical warfare capability, thus preserving the impression that the current state of readiness was such that chemical weapons could be employed on a massive scale and at any time, if necessary, whilst simultaneously arguing against the immediate use of chemical weapons in the current conflict.

Although hardly convinced by the report, Churchill decided to accept the assessment of his senior officials, at least for the time being. ${ }^{80}$ As it happened, Britain's Chiefs of Staff, and Churchill in particular, had no need to return to the subject of chemical warfare. In April 1945, after Allied forces had crossed the Lower Rhine, the Joint Intelligence Subcommittee concluded that Germany appeared unwilling and unprepared to initiate gas warfare to defend the territory of the Reich. However, it also counseled caution: "There remains the possibility that Hitler may recklessly order its use in the final stage of disintegration." ${ }^{, 81} \mathrm{He}$ never did. At the end of the month, Hitler ended his life in his bunker beneath the Reich Chancellery. Shortly thereafter, the unconditional surrender of the German army heralded the end of one of the most murderous regimes in modern history, and with it came the uncomfortable realization that Allied intelligence agencies had almost no knowledge of one of the greatest military and scientific secrets of the Second World War: nerve gas.

\section{References}

Avery, Donald. 2013. Pathogens for war: Biological weapons, Canadian life scientists, and North American biodefence. Toronto: University of Toronto Press.

Balfour, Sebastian. 2002. Deadly embrace: Morocco and the road to the Spanish Civil War. Oxford: Oxford University Press.

\footnotetext{
${ }^{80}$ TNA, PREM3/89, Personal Minute, Churchill to Ismay, 29 July 1944.

${ }^{81}$ TNA, PREM3/89, War Cabinet, Joint Intelligence Subcommittee, "Use of Chemical Warfare by the Germans", 23 April 1945.
} 
Balmer, Brian. 2001. Britain and biological warfare: Expert advice and scientific policy, 1930-65. Basingstoke: Palgrave Macmillan.

Brophy, L.P., and G.J.B. Fisher. 1959. The chemical warfare service: Organizing for war. Washington, DC: Department of the Army.

Buffetaut, Yves. 2008. Ypres April 22nd 1915: The first gas attack. Trans. C. Cook. Louviers: Ysec Editions.

Carter, G.B. 2000. Chemical and biological defence at Porton Down, 1916-2000. London: HMSO.

Carter, G.B., and G.S. Pearson. 1996. Past British chemical warfare capabilities. RUSI Journal 141: 59-68.

Charles, Daniel. 2005. Between genius and genocide: The tragedy of Fritz Haber, Father of chemical warfare. London: Jonathan Cape.

Chemical Corps Association. 1948. The chemical warfare service in World War II: A report of accomplishments. New York: Reinhold Publishing Corporation.

Chielens, Piet. 2014. The list of names and the second battle of Ypres. Public Lecture, University of Kent, November 5.

Churchill, Winston S. 1923. The world crisis, 1915. London: Thornton Butterworth Ltd.

Corrigan, Gordon. 2003. Mud, blood and poppycock. London: Cassell.

Cowell, F., et al. 2007. Chlorine as the first major chemical weapon. In An element of controversy: The life of chlorine in science, medicine, technology and war, ed. H. Chang, and C. Jackson, 220-254. London: BSHS Monographs.

Dendooven, Dominiek. 2005. Overview: 22 April 1915-Eyewitness accounts of the first gas attack. Unpublished paper given at the conference 1915. Innocence Slaughtered? Ypres, November 17-19.

Douglas, C.G. 1936. John Scott Haldane, 1860-1936. Obituary Notices of Fellows of the Royal Society 2 (5): 115-139.

Ede, A. 2011. Waiting to exhale: Chaos, toxicity and the origins of the U.S. chemical warfare service. Journal of Law, Medicine \& Ethics 39 (1): 28-33.

Evans, Rob. 2000. Gassed. British chemical warfare experiments on humans at Porton Down. London: House of Stratus.

Evans, Rob. 2007. Military scientists tested mustard gas on Indians. The Guardian, September 1.

Foulkes, C.H. 1934. "Gas!" The story of the special brigade. Edinburgh: W. Blackwood \& Sons.

Garner, J.P. 2003. Some recollections of Porton in World War I. Commentary. Journal of the RAMC 149 (2): 138-141.

Gibson, C.S. 1941. Sir William Jackson Pope. 1870-1939. Obituary Notices of Fellows of the Royal Society 3(9): 291-324.

Goebel, Stefan P., and Mark L. Connelly. 2017. Ypres. Great Battles. Oxford, New York: Oxford University Press. Forthcoming.

Goodman, Martin. 2008. Suffer and survive: Gas attacks, miners' canaries, spacesuits and the bends-The extreme life of J.S. Haldane. London: Pocket Books.

Grayzel, Susan R. 2012. At home and under fire: Air raids and culture in Britain from the Great War to the Blitz. Cambridge: Cambridge University Press.

Groehler, Olaf. 1989. Der lautlose Tod: Einsatz und Entwicklung deutscher Giftgase von 1914 bis 1945. Reinbek: Rowohlt.

Haber, Fritz. 1924. Fünf Vorträge aus den Jahren 1920-1923. Über die Darstellung des Ammoniaks aus Stickstoff und Wasserstoff; Die Chemie im Krieg; Das Zeitalter der Chemie; Neue Arbeitsweisen; Zur Geschichte des Gaskrieges. Berlin: Verlag von Julius Springer.

Haber, L.F. 1986. The poisonous cloud: Chemical warfare in the First World War. Oxford, New York: Oxford University Press.

Haldane, John S. 1925. Callinicus: A defence of chemical warfare. London: Kegan Paul.

Hammond, Peter M., and Gradon B. Carter. 2002. From biological warfare to healthcare. Basingstoke: Palgrave Macmillan.

Harris, Robert, and Jeremy Paxman. 1982. A higher form of killing: The secret history of chemical and biological warfare. London: Chatto \& Windus. 
Harrison, Mark, 2010. The medical war. British military medicine in the First World War. Oxford: Oxford University Press.

Historical Survey of the Porton Down Volunteer Programme. 2006. London, MoD, unpublished manuscript.

Hobbs, Abbi, Catherine Jefferson, Nicholas Coppeard, and Chris Pitt. 2007. Ethics, public relations, and the origins of the Geneva Protocol. In An Element of Controversy: The Life of Chlorine in Science, Medicine, Technology and War, ed. Hasok Chang, and Catherine Jackson, 255-295. London: BSHS Monographs.

Jacobs, Mariette. 1996. Zij, die vielen als helden... Inventaris van de oorlogsgedenktekens van de twee wereldoorlogen in West-Vlaanderen, vol. 2. Bruges: Provincie West-Vlaanderen.

Kershaw, Ian. 1998. Hitler, 1889-1936: Hubris. London: Allen Lane.

Klee, Ernst 1997. Auschwitz. Die NS-Medizin und ihre Opfer. Frankfurt am Main: S. Fischer Verlag.

Lloyd, Nick. 2006. Loos 1915. Stroud, Gloucestershire: Tempus.

Marrs, Timothy C., Robert L. Maynard, and Frederick R. Sidell. 1996. Chemical warfare agents. Toxicology and treatment. New York: John Wiley \& Sons.

McCamley, Nick J. 2006. The secret history of chemical warfare. Barnsley: Pen \& Sword Military.

Parker, John. 1996. The killing factory: The top secret world of germ and chemical warfare. London: Smith Gryphon.

Peters, R.A. 1959. The faith of a master in biochemistry. Biochemical Journal 71: 1-9.

Richter, D. 1994. Chemical soldiers: British gas warfare in World War I. London: Leo Cooper.

Roughton, F.J.W. 1949. Joseph Barcroft, 1872-1947. Obituary Notices of Fellows of the Royal Society 6 (18): 315-345.

Schmaltz, Florian. 2005. Kampfstoff-Forschung im Nationalsozialismus. Zur Kooperation von Kaiser-Wilhelm-Instituten, Militär und Industrie. Göttingen: Wallstein.

Schmaltz, Florian. 2006a. Neurosciences and research on chemical weapons of mass destruction in Nazi Germany. Journal of the History of Neurosciences 15: 186-209.

Schmaltz, Florian. 2006b. Otto Bickenbach's human experiments with chemical warfare agents and the concentration camp Natzweiler. In Man, Medicine and the State: The Human Body as an Object of Government-Sponsored Medical Research, ed. Wolfgang U. Eckart, 139-156. Stuttgart: Franz Steiner Verlag.

Schmaltz, Florian. 2006c. Pharmakologische Nevengasforschung an der Militärärztlichen Akademie und an den Universitäten Marburg, Danzig und Leipzig im Zweiten Weltkrieg. In Medizin im Zweiten Weltkrieg. Militärmedizinische Praxis und medizinische Wissenschaft im 'Totalen Krieg,' eds. Wolfgang U. Eckart and Alexander Neumann, 171-94. Paderborn: Schöningh.

Schmidt, Ulf. 2006. Cold War at Porton Down: Informed consent in Britain's biological and chemical warfare experiments. Cambridge Quarterly for Healthcare Ethics 15 (4): 366-380.

Schmidt, Ulf. 2007a. Karl Brandt. The Nazi Doctor. Medicine and Power in the Third Reich. London: Continuum.

Schmidt, Ulf. 2007b. Medical ethics and human experimentation at Porton Down: Informed Consent in Britain's Biological and Chemical Warfare Experiments. In History and Theory of Human Experimentation. The Declaration of Helsinki and Modern Medical Ethics, eds. Ulf Schmidt and Andreas Frewer, 283-313. Stuttgart: Steiner.

Schmidt, Ulf, and Andreas Frewer (eds.). 2007. History and theory of human experimentation. The Declaration of Helsinki and modern medical ethics. Stuttgart: Franz Steiner Verlag.

Schmidt, Ulf. 2012. Justifying chemical warfare. The origins and ethics of Britain's chemical warfare programme, 1915-1939. In Justifying War: Propaganda, Politics and the Modern Age, eds. David Welch and Joanne Fox, 129-58. Basingstoke: Palgrave.

Schmidt, Ulf. 2013. Accidents and experiments: Nazi chemical warfare research and medical ethics during the Second World War. In Military Medical Ethics for the 21st Century, ed. Don Carrick, and Michael L. Gross, 225-244. Farnham: Ashgate. 
Schmidt, Ulf. 2015. Secret science: A century of poison warfare and human experiments. Oxford, New York: Oxford University Press.

Shephard, Ben. 2000. A war of nerves. Soldiers and psychiatrists, 1914-1994. London: Jonathan Cape.

Spiers, Edward M. 1986. Chemical warfare. Basingstoke: Macmillan.

Spiers, Edward M. 2010. A history of chemical and biological weapons. London: Reaktion Books.

Stockholm International Peace Research Institute (SIPRI). 1971-1975. The Problem of chemical and biological warfare, vols. 1-6. Stockholm, New York: Almqvist \& Wiksell Humanities Press.

Stolzenberg, Dietrich. 2004. Fritz Haber-Chemist, Nobel Laureate, German, Jew. Philadelphia, PA: Chemical Heritage Press.

Sturdy, Steve. 1987. A co-ordinated whole: The life and work of J.S. Haldane. Unpublished PhD thesis, University of Edinburgh.

Sturdy, Steve. 1998. War as experiment: Physiological innovation and administration in Britain, 1914-1918: The Case of Chemical Warfare. In War, medicine and modernity, ed. Roger Cooter, Mark Harrison, and Steve Sturdy, 65-84. Stroud: Sutton.

Sturdy, Steve. 2011. The meanings of "Life": Biology and biography in the work of J.S. Haldane (1860-1936). Transactions of the Royal Historical Society 21: 171-191.

Szöllösi-Janze, Margit. 1998. Fritz Haber, 1868-1934: Eine Biographie. Munich: C.H. Beck.

Thompson, R.H.S., and A.G. Ogston. 1983. Rudolph Albert Peters. 13 April 1889-29 January 1982. Biographical Memoirs of Fellows of the Royal Society, 29: 495-523.

Thorpe, J.F. 1936. Herbert Brereton Baker, 1862-1935. Obituary Notices of Fellows of the Royal Society 1 (4): 523-526.

Tucker, Jonathan B. 2006. War of nerves: Chemical warfare from World War I to Al-Qaeda. New York: Pantheon Books.

Van Bergen, Leo. 2012. Monkey-Man, Man-Monkey: Neutrality and the discussions about the "Inhumanity" of poison gas in the Netherlands and International Committee of the Red Cross. First World War Studies 3: 1-23.

Van Moon, Courtland, and John Ellis. 1989. Project SPHINX: The question of the use of gas in the planned invasion of Japan. The Journal of Strategic Studies 12: 303-323.

Van Moon, Courtland, and John Ellis. 1996. United States chemical warfare policy in World War II: A captice of coalition policy. The Journal of Military History 60: 495-511.

Vilensky, Joel A. 2005. Dew of death. The Story of Lewisite, America's World War I weapon of mass destruction. Bloomington, IN: Indiana University Press.

Wheelis, Mark, Rósza Lajos, and Malcolm Dando (eds.). 2006. Deadly cultures. biological weapons since 1945. Cambridge, MA, London: Harvard University Press.

Open Access This chapter is licensed under the terms of the Creative Commons Attribution-NonCommercial 2.5 International License (http://creativecommons.org/licenses/by-nc/ $2.5 /$ ), which permits any noncommercial use, sharing, adaptation, distribution and reproduction in any medium or format, as long as you give appropriate credit to the original author(s) and the source, provide a link to the Creative Commons license and indicate if changes were made.

The images or other third party material in this chapter are included in the chapter's Creative Commons license, unless indicated otherwise in a credit line to the material. If material is not included in the chapter's Creative Commons license and your intended use is not permitted by statutory regulation or exceeds the permitted use, you will need to obtain permission directly from the copyright holder.

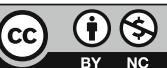

